\title{
Blended Learning in English Teaching and Learning: A Review of the Current Literature
}

\author{
Waheeb S. Albiladi \\ University of Arkansas, Fayetteville, USA \\ Khlood K. Alshareef \\ University of Arkansas, Fayetteville, USA
}

\begin{abstract}
This paper provides a review of the research related to the use of blended learning in English as a second/foreign language context. Blended learning is a relatively new field that combines traditional teaching approaches with distance and online learning. The use of blended learning has been emphasized by the recent research that examines the academic and social benefits of this teaching approach. Because it combines traditional and online teaching modes, the promise of blended learning rests on the strengths of both teaching approaches. The present review of the literature revealed that blended learning can be used effectively to develop language skills, enhance the English learning environment, and promote students' motivation toward learning the language. There is a dearth of literature that examines the challenges that face language teachers when using blended learning. Hence, more research has to be done to identify and deal with these challenges.
\end{abstract}

Index Terms—blended learning, English learning, educational technology, English teaching, ESL, EFL

\section{INTRODUCTION}

In the last few decades, blended learning has arisen as a new and significant educational trend. Research on blended learning is relatively new and is linked with other educational fields such as English teaching methodology, educational technology, computer-assisted language learning (CALL), and distance education (Picciano, Dziuban \& Graham, 2013). Blended learning has been defined to differentiate between this teaching and learning mode and traditional or online learning. To illustrate, Bonk and Graham (2012) defined blended learning as the combination of traditional face-to-face instruction with computer-assisted instruction. In another definition, Garrison and Vaughan (2008) indicated that blended learning was developed from the strengths of face-to-face and distance learning. It combines both types of learning as traditional classroom lecture and online learning are used in the teaching and learning process. When describing blended learning, Neumeier (2005) stated that "the most important aim of a Blended Learning design is to find the most effective and efficient combination of the two modes of learning for the individual learning subjects, contexts and objectives." (p. 164). Significantly, blended learning can be used instead of traditional or online learning because it promotes a stronger sense of engagement and community than traditional face-to-face or fully online teaching and learning methods (Tayebinik \& Puteh, 2013). In other words, blended learning allows for more learning opportunities that motivate students to participate in and outside of the class settings Senffner and Kepler (2015) pointed out blended learning is a flexible, scalable, and meaningful way of teaching and learning. That is, the online component of blended learning allows students to learn anytime in anywhere they prefer without being limited to groups or partners. According to Riel, Lawless, and Brown (2016) "Blended learning environments provide students with online and face-to-face places to meet, collaborate, and work on meaningful projects. Each of these spaces has particular benefits to successful learning" (p. 189). Rhem (2012) mentioned that the one of the unique characteristics of blended learning is that it allows teachers to provide classroom activities in two different settings: in person and online.

In addition, Zhang and Zhu (2018) noted that finding a suitable environment for all students is a difficult task, but the blended learning approach facilitates an "accessible, flexible, active, interactive, encouraging, and inspiring" teaching and learning environment (p. 268). In the language teaching and learning context, Neumeier (2005) provided a framework for designing a blended learning environment. This framework consists of six parameters that identify the key factors in designing a blended learning environment for language learning and teaching. These parameters are: (1) mode, (2) model of integration, (3) distribution of learning content and objectives, (4) language teaching methods, (5) involvement of learning subjects, and (6) location. Each one of these parameters is significant for language teachers to determine whether to integrate blended learning into their teaching practices.

Graham, Allen, and Ure (2003, 2005) identified three reasons for designing or using blended learning over other teaching options. These reasons are to improve teaching and learning pedagogies, increase access and flexibility, and increase cost-effectiveness. These three reasons might explain why instructors, trainers, or learners might choose blended learning over other types of teaching and learning. Moreover, Graham (2006) identified several levels of blended learning: activity-level blending, course-level blending, program-level blending, and institutional-level blending. Each one of these levels uses a combination of traditional ways of teaching and online elements depending on 
the type of learning, whether it is an activity, course, program or institution (Graham, 2006). Figure 1 illustrates the blended learning environment as it relates to traditional (face-to-face) and online learning.

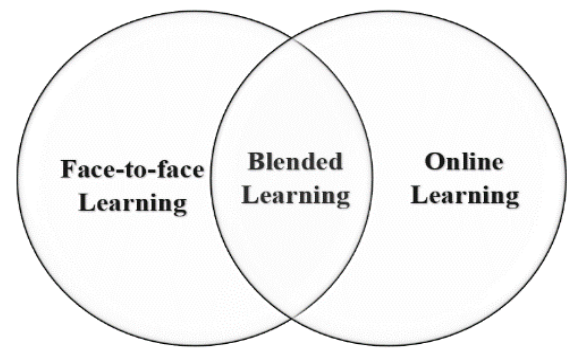

Figure1. Blended learning environment

\section{BLENDED LEARNING IN THE ESL/EFL CONTEXT}

Research on blended learning and English teaching and learning has increased as researchers have looked for ways to use this educational model in teaching English as a second/foreign language (ESL/EFL). Blended learning has been the focus of many research studies (Adas \& Bakir, 2013; Akbarov, Gönen, \& Aydoğan, 2018; Alias \& Pandian, 2012; Ghazizadeh \& Fatemipour, 2017; Grgurovic, 2011; Liu, 2013; Manan, Alias, \& Pandian, 2012; Shih, 2010; Yoon \& Lee, 2010; Zhang \& Zhu, 2018) that investigated the use and the effectiveness of blended learning in the ESL/EFL context. Several academic and social benefits of using this teaching approach have been identified. For instance, Marsh (2012) mentioned that the use of blended learning could provide many benefits to language learners over traditional teaching approaches. Some of these benefits include developing language learners' autonomy, providing more individualized language support, promoting collaborative learning, increasing students' interaction and engagement, providing opportunities to practice the language beyond the class settings, and improving the language skills of language learners. Even though many authors have defined blended learning, Osguthorpe and Graham (2003, p.228) perhaps have provided the most comprehensive definition in the following statement:

Those who use blended approaches base their pedagogy on the assumption that there are inherent benefits in face-toface interaction (both among learners and between learner and instructor) as well as the understanding that there are some inherent advantages to using online methods in their teaching. Thus the aim of those using blended learning approaches is to find a harmonious balance between online access to knowledge and face-to-face human interaction (p. 228).

In addition, Sharma and Barrett (2007) mentioned that several factors influence the uptake of a blended learning approach in language courses. These factors are teachers' positive or negative attitudes toward technology use, learners' proficiency levels, teachers' training, teachers' and students' accessibility to technology, and cost. Each one of these factors plays a vital role in decisions regarding implementing a blended learning approach in language classrooms.

TABLE I

OVERVIEW OF THE FINDINGS RELATED TO THE USE OF BLENDED LEARNING IN ESL/EFL CONTEXT

\begin{tabular}{|l|l|}
\hline Findings & Research studies \\
\hline $\begin{array}{l}\text { BL as a means to develop } \\
\text { students' language skills }\end{array}$ & $\begin{array}{l}\text { Adas \& Bakir (2013); Grgurovic (2011); Ghazizadeh \& } \\
\text { Fatemipour (2017); Shih (2010); Tosun (2015) }\end{array}$ \\
\hline $\begin{array}{l}\text { BL as a means to increase } \\
\text { students' motivation and } \\
\text { engagement }\end{array}$ & $\begin{array}{l}\text { Banditvilai (2016); Manan, Alias \& Pandian (2012); } \\
\text { Marsh, (2012); Liu (2013); Yoon \& Lee (2010) }\end{array}$ \\
\hline $\begin{array}{l}\text { BL as a means to improve the } \\
\text { learning environment }\end{array}$ & $\begin{array}{l}\text { Akbarov, Gönen \& Aydoğan (2018); Ja'ashan (2015); } \\
\text { Marsh (2012); Zhang \& Zhu (2018) }\end{array}$ \\
\hline
\end{tabular}

Significantly, after examining the literature surrounding the use of blended learning in ESL/EFL classrooms, it was found that this teaching model can be used to develop various English language skills (Adas \& Bakir, 2013; Ghazizadeh \& Fatemipour, 2017; Grgurovic, 2011; Shih, 2010), improve the learning environment (Banditvilai, 2016; Liu, 2013; Manan, Alias \& Pandian, 2012; Yoon \& Lee, 2010), and enhance students' engagement (Akbarov, Gönen \& Aydoğan, 2018; Ja'ashan, 2015; Zhang \& Zhu, 2018). Table 1 illustrates the research surrounding the use of blended learning in the ESL/EFL context.

\section{A. Blended Learning and Language Skills}

Many studies (Adas \& Bakir, 2013; Grgurovic, 2011; Ghazizadeh \& Fatemipour, 2017; Shih, 2010) have indicated that blended learning can be used effectively to develop the language skills of language learners. For instance, learners' speaking, listening, reading, and writing abilities can be developed when using blended learning instead of traditional face-to-face or fully online approaches. 
As a way of illustration, in a quasi-experimental study, Ghazizadeh and Fatemipour (2017) examined the effect of blended learning in developing the reading skills of English language learners. Specifically, the study aimed to investigate whether blended learning can be used to develop the reading proficiency of sixty intermediate-level Iranian EFL learners. The participants were randomly assigned to two groups: an experimental group, which received classroom instructions and blended learning focused on the reading skills, and a control group, which received a more traditional approach to English teaching. The two groups were tested before and after the treatment to determine the learners' reading proficiency level. After comparing the two groups using a t-test, the researchers found that the use of blended learning resulted in a statistically significant positive effect on the reading proficiency of the EFL learners. In other words, Ghazizadeh and Fatemipour (2017) asserted that using blended learning with language learners has a direct impact on enhancing the reading skills of language learners. Based on the study results, the researchers also stated that blended learning facilitates the learning process and can be successfully adopted in English reading classes.

Likewise, Adas and Bakir (2013) examined the use of a blended learning strategy in developing the writing competency of EFL learners. Specifically, the study aimed to determine whether blended learning can be an effective strategy that helps in increasing students' overall performance in writing. Sixty EFL learners in a Palestinian university participated in the study. The students were divided into two groups: one was taught English writing using the traditional face-to-face approach, while the other group was taught using a blended learning model. At the end of the teaching period, the researchers found that the group that was taught using a blended learning performed better in writing than the other group. In other words, the use of blended learning helped in developing the writing competencies of the participating EFL learners. The researcher concluded by stating that using blended learning developed many aspects of the participants' writing such as grammar, spelling, punctuation, and paragraph coherence.

Moreover, Grgurovic (2011) investigated the use of blended learning in an ESL context. Using Neumeier's (2005) framework of blended learning, the study aimed to determine how blended learning is used in ESL classes and how both face-to-face and distance learning are integrated. The study was conducted in a speaking and listening class in an intensive English program in the USA. The participants were 19 ESL students and one English instructor. The research method included observing the language classes, surveying the students, and interviewing the instructor to explore the effectiveness of this learning model. The findings indicated that blended learning could be successfully and effectively used to teach all language skills. Both teachers and students shared positive perceptions and attitude toward integrating blended learning in English teaching. They believed that the use of online teaching added to the traditional ways and improved the students' language learning process. The researcher concluded by stating that blended learning can be used effectively to teach English in foreign/second language programs.

Similarly, in another study, Shih (2010) investigated the use of a blended learning approach to teach an English course. In particular, the study aimed to design a blended learning environment in which instructional blogging is used with ESL learners. Forty-four college ESL learners were involved in the study. Several research methods were used to investigate the effects of the blended learning mode, including students' satisfaction survey, teachers' and students' feedback, students' self-reflection, and interviews. The results of the study indicated that using the blended learning mode with video-based blogs resulted in many benefits such as improving the students' speaking skills, developing a sense of autonomy and collaboration, and enhancing the learning process. Shih (2010) stated that one of the benefits of using blended learning approach is to improve students' speaking skills as well as other language abilities such as their grammar, pronunciation, facial expression, and eye contact.

However, other studies indicated that the use of blended learning does not always have a direct impact on language skills. For instance, Tosun (2015) investigated the effect of using a blended learning approach in teaching English vocabulary. The study also explored English language learners' perceptions about blended learning in learning English vocabulary. The study included 40 students studying at two classes in an intensive English program in Turkey. The participants were divided into two groups: an experimental group that studied the target vocabulary through a blended learning approach, and a control group that was taught the same vocabulary using the traditional teaching method (faceto-face instruction). At the end of the instruction period, both groups were tested to determine their vocabulary knowledge. The findings indicated that even though the students were satisfied with blended learning as a teaching strategy, the use of a blended learning strategy did not have any positive effect on students' vocabulary knowledge. Tosun (2015) mentioned that their findings did not resonate with many previous research studies that linked the use of blended learning to the development of language skills. Tosun added that the one possible explanation of these results is the short duration of the study.

All in all, in the ESL and EFL context, research shows that blended learning can be used effectively to develop the language competencies of English language learners. The reviewed studies indicate that language teachers could utilize blended learning as a teaching model to develop various skills such as reading, writing, speaking, and vocabulary knowledge.

\section{B. Students' Motivation and Engagement}

Perhaps one of the most cited benefits of blended learning in the ESL/EF context is related to students' motivation, satisfaction, and engagement. Language learners usually showed their satisfaction when both approaches (traditional face-to-face and online) were combined. The strength of blended learning rests in using both teaching approaches effectively, and that motivates students to interact and engage in the language learning process. 
To illustrate, Banditvilai (2016) conducted a study that examined the use of blended learning to enhance English learners' language skills and learning autonomy in an Asian university. The study was carried out in an English for specific purpose class and included 60 undergraduate students majoring in English. The study aimed to understand students' attitudes toward blended learning in English learning. The researcher used e-lessons, a questionnaire, and achievement tests as instruments to collect data. The findings of the study indicated that the use of an online approach aligned with classroom instruction enhances the language skills of language learners. Also, it was found that blended learning can be used effectively to increase autonomous learning and learners' motivation. Banditvilai mentioned that students can learn and practice their language anytime anywhere they want and that is what makes the blended learning approach preferable for language learners. The research concluded by stating that "Blended learning is a valuable concept that can be used to more successfully achieve teaching goals." (p.227).

Furthermore, a study conducted by Liu (2013) examined the effectiveness of blended learning in an academic English writing course at a major university in Beijing, China. The study aimed to evaluate several aspects of blended learning such as course design, material presentation, students' involvement, and classroom assessment. The class in which the study was conducted included 90 minutes of classroom meetings each week and one more online hour after the class. Based on the teacher's reflection and students' evaluation of the course, it was found that the students highly appreciated the use of blended learning strategy because it had many advantages such as motivating autonomous learning, increasing classroom interactions, eliminating communication anxiety, and improving learners' academic writing competencies. The researcher concluded by stating that because it allows for two different types of learning interactions, the use of blended learning is more motivating and inspiriting for language learners.

In another study, Manan, Alias, and Pandian (2012) examined the effectiveness of blended teaching using one of the social media features. Specifically, the researchers used Facebook groups along with face-to-face instruction in an ESL context. The study included 30 undergraduate ESL learners enrolled in an ESL course at one of the public universities in Malaysia. The students were taught using the conventional classroom teaching as well as online using Facebook groups. According to the researchers, after observing students learning through this blended learning strategy and asking their perceptions, it was found that the majority of students showed appositive perceptions toward this learning strategy. The students said that using a Facebook group along with classroom instructions was interesting and authentic. They were motivated to interact and collaborate, and that is one of the significant strengths of blended learning. You report the results, but there is not really a clear sense of the 'how' - what is it about blended learning, especially the technological side perhaps, that allows for student motivation to be high, and autonomy? What is the inherent quality that leads to success?

Likewise, Yoon and Lee (2010) investigated students' perspectives and the effectiveness of blended learning as a teaching strategy in an ESL writing class. For more than 16 weeks, 47 university language learners in two writing classes participated in the study. Four sources of data were used: questionnaires, pretest, post-test, and midterm examination. The results indicated that students showed positive attitude and perceptions toward the use of a blended learning approach in L2 writing classes. The students believed that this learning approach is useful, motivating, and interacting. Moreover, the use of blended learning resulted in a better performance in students' writing abilities. The researcher stated that the use of blended learning increased students' motivation and promoted many significant aspects in language learning such as interaction, autonomy, and collaboration. Yoon and Lee (2010) indicated that the students "seemed to appreciate the opportunities for interaction and were satisfied with blended learning in L2 writing" (p.198).

Ultimately, the use of blended learning has been linked to increasing students' motivation and engagement. Combining the traditional and online teaching modes allows language learners to interact with the language inside and outside of classroom settings. Different studies showed that this type of teaching facilitates language learning and improves students' participation and engagement.

\section{Blended Learning and the Learning Environment}

The review of the literature related to blended learning revealed that one of the significant benefits of using this teaching approach in the ESL/EFL context is enhancing the language learning environment, which plays a vital role in the learning and teaching process. Several studies have indicated that relying on a blended learning strategy will result in improving the teaching and learning process.

Zhang and Zhu (2018) conducted a study in which blended learning mode was compared to traditional face-to-face learning mode. Specifically, the study investigated the effectiveness of blended learning compared to the traditional methods used to teach English as a second language in China. The sample size of the study included 5376 students who were enrolled in ESL courses at a major university in Beijing. The researchers analyzed a large database that included students who were enrolled in ESL courses and their performance, gender, grade, and discipline. The results indicated that students who were studying using a blended learning mode had better academic achievement in ESL courses when compared with other students who were taught using the face-to-face mode. In other words, students in blended learning settings performed better in ESL courses than students in face-to-face settings. The researcher indicated that the results showed that the use of blended learning has a positive impact on student learning outcomes.

Another study conducted by Akbarov, Gönen and Aydoğan (2018) investigated students' attitudes toward blended learning in the EFL context. The study's sample involved 162 English language learners. The researchers employed a questionnaire, which included questions that examined the learners' perceptions and attitudes toward blended learning 
compared to the traditional classroom in EFL classes. The study's results indicated that most of the EFL students prefer blended learning over the traditional approach of English teaching because it enhances their motivation to learn which resulte in improving of the learning process. In other words, they believed that blended learning has a direct impact on their learning. Nevertheless, the participants reported that they prefer to be tested using traditional ways rather than digital ways. The findings from Akbarov et al. (2018) also suggested the participants believed that the use of blended learning resulted in developing their English proficiency levels. As such, the researchers concluding by stating that blended learning is an effective learning mode that can be used in an EFL context to improve the teaching and learning process.

Similarly, Ja'ashan (2015) investigated students' perceptions and attitudes toward the use of blended learning in an EFL English course in Bisha University, Saudi Arabia. To understand the students' perceptions and attitudes, a survey was administrated and involved 130 undergraduate English learners. Analysis of the data indicated that students showed positive perceptions toward the use of blended learning in English teaching. The participants were satisfied with blended learning because they believe this teaching approach can be used to enhance their language skills, develop their learning autonomy, improve student-teacher interaction, enhance the learning process, and allow for interesting learning experiences. The researcher also reported some disadvantages of using blended learning mode as it requires long time to prepare and implement blended lessons. Teachers have to apply teaching and learning activities for two modes (face-toface and online). Ja'ashan (2015) concluded by stating that the participants mentioned that blended learning is more convenient than traditional face-to-face teaching, and that it increased their motivation to learn and develop their skills accordingly.

In summary, research shows that blended learning can be used to enhance the learning process and outcomes of language learners. English language learners usually show positive perceptions and attitudes toward the use of blended learning as an English teaching approach. These positive perspectives are derived from several directions, including, but not limited to, developing students' language skills in interacting and engaging settings, fostering the learning process, and providing opportunities to be independent learners.

\section{Challenges of Using BLEnded LEARning IN ESL/EFL CONTEXT}

Even though research regarding blended learning focuses on the benefits of this teaching mode, some challenges have been identified for this teaching approach. Perhaps one of the most comprehensive discussions to shed light on the issues of blended learning can be found in Bonk's and Graham's (2012) work. The researchers identified six major issues arising when designing a blended learning environment. These issues are: (1) "The role of live interaction"; (2) "the role of learners' choices and self-regulation"; (3) "models for support and training"; (4) "dealing with the digital divide"; (5) "cultural adaptation"; and (6) "finding balance between innovation and production" (pp.14-16). The first issue is the role of live interaction. This is related to the amount of interaction in both learning mode, face-to-face, and online learning. The second challenge is understanding the role of learners' choices and self-regulation. This means understanding students' choices regarding which kinds of blended learning they participate in, and how a teacher can guide and affect their learning when using blended learning. The third issue is related to the models used for support and training. To use a blended learning approach more effectively, support is needed for both technological aspects as well as pedagogical and instructional teaching. The fourth challenge is the digital divide. Bonk and Graham (2012) mentioned that "the divide between the information and communication technologies available to individuals and societies at different ends of the socioeconomic spectrum can be great" (p. 15). The fifth issue that arises when designing a blended learning course is cultural adaptation. This is related to the materials that are used in both modes and their relation to the students' culture. The final issue mentioned by Bonk and Graham (2012) is trying to find a balance between innovation and production. According to Bonk and Graham (2012), in designing a blended learning classroom, a tension might arise between trying to use the new technological innovation and the ability to produce costeffective results.

Also, Riel et al. (2016) indicated six sets of challenges that teachers encounter during the implementation process of a blended learning curriculum. First, teachers might face issues when working with students on curriculum activities. Students might have difficulty communicating with peers to finish the given tasks. Second, there might be challenges with student self-management. When using a blended learning approach, teachers might have difficulty keeping students focused on their task, so teachers need to keep activities relevant and active. Third, establishing work expectations is another challenge that might face teachers when implementing blended learning. This refers to setting achievable goals and objectives related to students' learning. Fourth, curriculum orchestration concerns organizing the work and finding time to conduct the lesson as well as a time frame to finish the work. Fifth, another challenge that arises when implementing the blended learning method is outside-of-classroom challenges. One example could be participating in out of the class activities. Scheduling a time for students to participant in out of the class activities can be difficult. Sixth, teachers might face technology challenges. These are the technological problems that arise during the implementation process of blended learning.

\section{CONCLUSION}


Blended learning is a teaching strategy that combines both traditional face-to-face and online teaching in one setting. It is a growing trend in the age of technological development. Blended learning is a promising idea that has linked together many significant fields such as teaching methodology, educational technology, online teaching, and learning. The use of blended learning in the ESL/EFL context has received much attention as a way to teach and learn English. Research has shown that using blended learning instead of traditional teaching or online teaching approaches alone results in many benefits not only on students' learning but also on the learning environment. Some of these benefits include enhancing the English learning process, developing language skills, and improving the English learning environment. Despite these benefits, the use of blended learning can be associated with some challenges. However, there is a dearth of literature that examines the issues that face teachers when using a blended learning approach in the ESL/EFL context. More research has to be done to explore ESL/EFL teachers' perspectives regarding the challenges that they encounter when using blended learning in English teaching and learning.

\section{REFERENCES}

[1] Adas, D., \& Bakir, A. (2013). Writing difficulties and new solutions: Blended learning as an approach to improve writing abilities. International Journal of Humanities and Social Science, 3(9), 254-266.

[2] Akbarov, A., Gönen, K., \& Aydoğan, H. (2018). Students' attitudes toward blended learning in EFL context. Acta Didactica Napocensia, 11(1), 61-68. doi:10.24193/adn.11.1.5.

[3] Banditvilai, C. (2016). Enhancing Students' Language Skills through Blended Learning. Electronic Journal of e-Learning, 14(3), 220-229.

[4] Bonk, C. J., \& Graham, C. R. (2012). The handbook of blended learning: Global perspectives, local designs. San Francisco, CA: John Wiley \& Sons.

[5] Garrison, D. R., \& Vaughan, N. D. (2008). Blended learning in higher education: Framework, principles, and guidelines. San Francisco, CA: John Wiley \& Sons.

[6] Ghazizadeh, T., \& Fatemipour, H. (2017). The effect of blended learning on EFL learners' reading proficiency. Journal of Language Teaching and Research, 8(3), 606-614. doi:10.17507/jltr.0803.21.

[7] Graham, C. R. (2006). Blended learning systems. In Bonk, C. J. \& Graham, C. R. (Eds.). (in press). Handbook of blended learning: Global Perspectives, local designs. (3-21). San Francisco, CA: John Wiley \& Sons

[8] Graham, C. R., Allen, S., \& Ure, D. (2005). Benefits and challenges of blended learning environments. In M. Khosrow-Pour (Ed.), Encyclopedia of information science and technology (pp. 253-259). Hershey, PA: Idea Group.

[9] Graham, C. R., Allen, S., Ure, D., (2003). Blended learning environments. A review of the research literature. Unpublished manuscript, Brigham Young University.

[10] Grgurovic, M. (2011). Blended learning in an ESL class: A case study. Calico Journal, 29(1), 100-117.

[11] Ja'ashan, M. M. (2015). Perceptions and attitudes towards blended learning for English courses: A case study of students at University of Bisha. English Language Teaching, 8(9), 40-50. doi: 10.5539/elt.v8n9p40.

[12] Liu, M. (2013). Blended Learning in a University EFL Writing Course: Description and Evaluation. Journal of Language Teaching \& Research, 4(2), 301-309. doi:10.4304/jltr.4.2.301-309.

[13] Manan, N. A. A., Alias, A. A., \& Pandian, A. (2012). Utilizing a Social Networking Website as an ESL Pedagogical Tool in a Blended Learning Environment: An Exploratory Study. International Journal of Social Sciences \& Education, 2(1), 1-9

[14] Marsh, D. (2012). Blended learning: Creating learning opportunities for language learners. New York, NY: Cambridge University Press.

[15] Neumeier, P. (2005). A closer look at blended learning: Parameters for designing a blended learning environment for language teaching and learning. ReCALL, 17, 163-178. doi: 10.1017/S0958344005000224.

[16] Osguthorpe, R. T. \& Graham, C. R. (2003). Blended learning environments: Definitions and directions. The Quarterly Review of Distance Education, 4(3), 227-233.

[17] Picciano, A. G., Dziuban, C., \& Graham, C. R. (2013). Blended learning: Research perspectives. New York, NY: Routledge Publication.

[18] Rhem, J. (2012). Blended learning: Across the disciplines, across the academy. Sterling, VI: Stylus Publishing, LLC.

[19] Riel, J., Lawless, K. A., \& Brown, S. W. (2016). Listening to the teachers: Using weekly online teacher logs for ROPD to identify teachers' persistent challenges when implementing a blended learning curriculum. Journal of Online Learning Research, 2(2), 169-200.

[20] Senffner, D., \& Kepler, L. G. (2015). Blended learning that works. Alexandria, VA: Association for Talent Development

[21] Sharma, P., \& Barrett, B. (2007). Blended learning: Using technology in and beyond the language classroom. Oxford, UK: Macmillan education.

[22] Shih, R. C.(2010). Blended learning using video-based blogs: Public speaking for English as a second language students. Australasian Journal of Educational Technology, 26(6), 883-897doi: https://doi.org/10.14742/ajet.1048.

[23] Tayebinik, M., \& Puteh, M. (2013). Blended Learning or E-learning? International Magazine on Advances in Computer Science and Telecommunications (IMACST), 3(1), 103-110. doi: https://ssrn.com/abstract=2282881.

[24] Tosun, S. (2015). The effects of blended learning on EFL students' vocabulary enhancement. Procedia-Social and Behavioral Sciences, 199(1), 641-647. https://doi.org/10.1016/j.sbspro.2015.07.592.

[25] Yoon, S. Y., \& Lee, C. H. (2010). The perspectives and effectiveness of blended learning in L2 writing of Korean university students. Multimedia Assisted Language Learning, 13(2), 177-204.

[26] Zhang, W., \& Zhu, C. (2018). Comparing learning outcomes of blended learning and traditional face-to-face learning of university students in ESL courses. International Journal on E-Learning, 17(2), 251-273. 
Waheeb S. Albiladi is a Ph.D. candidate in the TESOL program at the University of Arkansas. He has 8 years of experience in teaching English as a second/foreign language. His research interests include ESL/EFL pedagogy, educational technology, the use of social media in English teaching and learning, and bilingual education.

Khlood K. Alshareef is a Ph.D. student in the gifted and talented education at the University of Arkansas. Her research interests include gifted education, differentiated instructions, creativity, and cooperative learning. 